\title{
Nem fertőző betegségek versus társadalmi hatásokhoz kapcsolódó betegségek elnevezés
}

\author{
Non-communicable diseases versus socially transmitted conditions term
}

\author{
Szerző: Vokó Zoltán $\bowtie$ \\ ELTE TáTK Egészségpolitika és Egészség-gazdaságtan Tanszék
}

Beküldve: 2018. 02. 14.

doi: $10.24365 /$ ef.v59i1.240

Kulcsszavak: nem fertőző betegségek, társadalmi hatások, szakkifejezés

Keywords: non-communicable diseases, social effects, term

Az Egészségfejlesztés folyóirat LVIII. évfolyam, 2017. 4. számának közleményében a szerkesztőség javaslatot tett egy, a The Lancetben megjelent cikk nyomán arra, hogy a jövőben a „nem fertőző betegségek" elnevezés helyett használjuk a „társadalmi hatásokhoz kapcsolódó betegségek” elnevezést. $(1,2,3)$

A The Lancet-beli cikkben felsorakoztatott fóbb érvek a névváltoztatás mellett:

- „a betegségcsoport „elhanyagolásában” szerepet játszhat a fogalom negatív csengése, melyet a "nem" szó idéz elol";

- „számos nem fertőző megbetegedés részben vagy teljes egészében fertőző tulajdonsággal is bír;

- „a nem fertőző betegségek visszaszorításához elsősorban az egyéni egészségtényezők megváltoztatását (pl. a dohányzásról való leszokást) szokás célul kitǔzni a populációs szakpolitikák megváltoztatására irányuló intézkedések helyett".

A The Lancet közleményének szerzői szerint a nem fertőző betegségek hatékonyabb visszaszorítása érdekében, azért, hogy „jelentős változás következzen be, először is a nem fertőző betegségek nevének és tartalmának újragondolása szükséges. A cél olyan elnevezés megfogalmazása, mely pontosabban kifejezi a csoportba tartozó betegségeket, illetve "marketing" szempontból is „jobban eladható".
Két észrevételt szeretnék tenni a javaslattal kapcsolatosan:

Egyrészt sem a Lancet-közlemény szerzői, sem az Egészségfejlesztés folyóirat szerkesztői nem szolgáltatnak semmiféle bizonyítékot arra vonatkozóan, hogy a betegségcsoport elhanyagolásában a névnek bármilyen szerepe lenne. Már önmagában az elhanyagolás is kérdéses és viszonylagos, amikor a HIV-AIDS járvány mellett az egyetlen egészségprobléma, amelyet az ENSz Közgyúlése napirendjére tűzött a nem fertőző megbetegedések visszaszorítása volt. ${ }^{(4)}$ Azóta számos cselekvési program született, valamint egy globális monitorozási keret került elfogadásra és megvalósításra az előrehaladás követésére és értékelésére. ${ }^{(5,6)} \mathrm{Az}$ összes jelentős nemzetközi egészségstratégia fontos eleme ez a terület (lásd pl. a WHO Egészség 2020 stratégiáját!), és számos ország népegészségügyi programjának fontos eleme, ahogy hazaiaknak is az volt már a Kertai Program óta. ${ }^{(7,8)}$ Ez persze még nem jelenti azt, hogy megfelelö léptékben és eredményességgel folynának a nem fertőző betegségek visszaszorítására irányuló programok világszerte, de elhanyagolásról ma már nem beszélhetünk.

Másrészt, ahogy a Lancet-közlemény szerzői maguk is elismerik, „nincs egyedüli jellemző, amely minden nem fertőző betegségre igaz lenne és teljesen elválasztaná őket a klasszikus fertőző betegségektől." ${ }^{3}$ Valóban, a fertőző megbetegedések és a nem 
fertőző betegség elnevezések sem tökéletesen diszkriminálnak a két betegségcsoport között, mert egyes nem fertőző betegségek etiológiájában fertőző ágensek szerepet játszanak, még ha e betegségek nem is felelnek meg a Koch-féle posztulátumoknak. Véleményem szerint ennek ellenére még mindig ez a nevezéktan különíti el a két betegségcsoportot a legjobban, de legalábbis feltétlenül jobban, mint a javasolt új név, hiszen a fertőző betegségek legalább annyira társadalmi hatásokhoz kapcsolódó betegségek, mint a nem fertőzőek, gondoljunk csak a járványok kialakulásának fő tényezőire vagy kontrolljukra!

A név ugyan marketingkommunikációs szempontból fontos, de véleményem szerint a szerzők túlértékelik a jelentőségét abban, hogy mennyiben járulhat hozzá a nem fertőző betegségek visszaszo- rításához a név megváltoztatása. Ugyanakkor a névváltoztatási javaslat iránti motivációnak a névválasztásban tükröződő fontos eleme az a vélemény, hogy nem kellően ismert a nem fertőző betegségek társadalmi meghatározottsága sem a közvélemény számára, sem a döntéshozók körében, sem az orvostársadalomban. A javasolt névváltoztatás azonban szerintem a fenti érvek miatt nem jó eszköz arra, hogy felhívjuk a figyelmet erre a hiányosságra. Helyette hatékony egészségkommunikációt kellene folytatni erről a kérdésről, annak érdekében, hogy tudatosodjon a döntéshozókban és a közvéleményben, hogy melyek a nem fertőző betegségek meghatározó tényezői, és milyen módon lehet ezeket kedvező irányba befolyásolni. Ez az első lépése annak, hogy össztársadalmi méretekben a szükséges intézkedések, programok meg is valósuljanak.

${ }^{1}$ Szerkesztőségi közlemény. A nem fertőző betegségek: definíció újratöltve. Non-communicable diseases: definition reloaded. Egészségfejlesztés. 2017. http://dx.doi.org/10.24365/ef.v58i4.214

2 Luke N Allen, Andrea B Feigl: What's in a name? A call to reframe non-communicable diseases. doi: http://dx.doi.org/10.1016/S2214-109x(17)30001-3

${ }^{3}$ Luke N Allen, Andrea B Feigl: Reframing non-communicable diseases as socially transmitted conditions. doi: http://dx.doi.org/10.1016/S2214-109x(17)30200-0

${ }^{4}$ UN General Assembly Resolution on Political Declaration of the High-level Meeting of the General Assembly on the Prevention and Control of Non-communicable Diseases (A/RES/66/2). 2012. http://www.who.int/nmh/events/un ncd summit2011/political declaration en.pdf?ua=1 Elérve: 2018. 03.05.

${ }^{5}$ 66th World Health Assembly Resolution 10 on Follow-up to the Political Declaration of the High-level Meeting of the General Assembly on the Prevention and Control of Non-communicable Diseases. 2013. http://apps.who.int/gb/ebwha/pdf_files/WHA66/A66_R10-en.pdf?ua=1 Elérve: 2018. 03. 05.

${ }^{6}$ WHO Regional Office for Europe. Action Plan for the Prevention and Control of Noncommunicable Diseases in the WHO European Region. 2016. http://www.euro.who.int/_data/assets/pdf file/0008/346328/NCD-ActionPlanGB.pdf?ua=1 Elérve: 2018. 03. 05.

7 WHO Regional Office for Europe. Health 2020 policy framework and strategy. 2012. http://www.euro.who.int/_data/assets/pdf_file/0009/169803/RC62wd09-Eng.pdf Elérve: 2018. 03. 05.

8 1030/1994. (IV. 29.) Korm. határozat a hosszú távú egészségfejlesztési politika alapelveiről 